\title{
Abatacept induced granulomatous hepatitis with a sarcoidosis- like reaction: a blinded trial in mice
}

\author{
Sultan M. Almogairen(1)
}

\begin{abstract}
Background: Abatacept is increasingly used for rheumatoid arthritis (RA) and juvenile idiophathic arthritis (JIA) treatment. However little is known about the risk of hepatotoxicity. The aim of this study was to determine whether the inhibition of the T cell CD28 receptor by abatacept results in acute hepatitis in BALB/c mice.

Methods: Twenty BALB/C mice were studied. Ten mice received subcutaneous (SC) injection of abatacept $(0.25 \mathrm{mg}$ per $25 \mathrm{~g}$ body weight per $0.03 \mathrm{ml}$ normal saline) at 0, 2, 4 and 8 weeks. For the control group, 10 mice received a SC injection of normal saline (NS) $(0.03 \mathrm{ml})$. At the 10th week post injection, the mice were sacrificed, and histopathological studies were conducted.

Results: Of the abatacept-treated group, 3/10 mice died. Liver histology for the abatacept-treated group showed that 6/7 displayed histopathological changes in the lobular cellular infiltrates of eosinophils, lymphocytes and histiocytes, in addition to granuloma formation. In contrast, only minimal inflammation was observed in 3/10 mice in the control group ( $p=0.036)$.

Conclusion: Abatacept may play a role in inducing granulomatous hepatitis with a sarcoidosis-like reaction. Additional data including transaminases, antinuclear antibodies (ANA), Antimitochondrial antibodies (AMA) and other auto antibodies should be tested.
\end{abstract}

Keywords: Abatacept, Granuloma, Hepatitis, Sarcoidosis

\section{Background}

Rheumatoid arthritis (RA) treatments have evolved in the last 20 years with the widespread usage of methotrexate, followed by the development of Tumor necrosis factor (TNF) alpha inhibitors [1, 2]. Patients who fail Tumor Necrosis Factor Inhibitor (TNFi) therapy can switch to another TNFi (TNFi cyclers) or to a non-TNFi drug, such as abatacept, rituximab, tocilizumab. Alternatively, patients can also be prescribed the targeted synthetic Disease-Modifying Anti Rheumatic Drugs (DMARD) tofacitinib (non-TNFi switchers) [3-8].

In the early 1990s, Linsley et al. synthesized a fusion protein using a human IgG1 and a modified Fc region of Cytotoxic T Lymphocyte Antigen-4 (CTLA4), which was capable of inhibiting the immune response in vitro. This

Correspondence: salmogairin@ksu.edu.sa; almogairin@gmail.com Rheumatology Division, Department of Medicine, College of Medicine, King Saud University, P O Box 2925, Riyadh 11461, Saudi Arabia protein was originally known as the CTLA4-Ig and it was subsequently named abatacept $[9,10]$. Abatacept binds to the CD80/86 receptor of an antigen-presenting cell. This interaction blocks the activation of the CD28 receptor on T cells $[11,12]$.

In the global safety database overall frequencies of adverse events (AEs; $88.8 \%$ versus $85.1 \%$ ), serious AEs (SAEs; $14.0 \%$ versus $12.5 \%$ ) and malignancies (1.4\% versus $1.1 \%)$ were statistically similar in abatacept-treated-versus placebo-treated patients, respectively. This was found to be the case regardless of the potential relationship between the study therapies. Discontinuation of the drug therapy as a result of SAEs was $2.8 \%$ in the abatacept group versus $1.6 \%$ in the placebo group. The frequency of serious infections was low overall (3.0\% versus $1.9 \%)$ in the abatacept-treated versus placebo-treated patients, respectively $[13,14]$.

(c) The Author(s). 2019 Open Access This article is distributed under the terms of the Creative Commons Attribution 4.0 International License (http://creativecommons.org/licenses/by/4.0/), which permits unrestricted use, distribution, and reproduction in any medium, provided you give appropriate credit to the original author(s) and the source, provide a link to the Creative Commons license, and indicate if changes were made. The Creative Commons Public Domain Dedication waiver (http://creativecommons.org/publicdomain/zero/1.0/) applies to the data made available in this article, unless otherwise stated. 
Abatacept has no known hepatotoxic effects except for causing an elevation in alanine transaminase and aspartate transaminase levels, which were reported in forty six out of eighteen hundred and seventy nine (46/1879) patients $(2.4 \%)$ and $26 / 1879$ patients (1.4\%), respectively. There are no hepatic contraindications for abatacept treatment except for severe liver failure. This limits the use of all drugs, and pharmacokinetic and pharmacodynamic studies are required to define the adverse effects of abatacept use, if any $[15,16]$.

Compared to the number of human studies, there are no controlled experimental animal studies that have examined the histology of abatacept-induced liver injury. Therefore, this study determined the effect of blocking the cluster of differentiation 28/ cytotoxic T-lymphocyte-associated antigen 4/B7 (CD28/ CTLA-4/B7) costimulatory pathway by SC injection of abatacept with respect to the development of acute hepatitis in BALB/c mice.

\section{Methods}

Twenty BALB/c male mice (average weight of $25 \mathrm{~g}$ and they were not previously subjected to therapy or experiments) were purchased from the Faculty of Pharmacy at King Saud University (Kingdom of Saudi Arabia). This study was approved by King Saud University, Faculty of Medicine Institutional review board (IRB) through the institution's research ethics board (REB) approval number (E-14-1300). This research was conducted in compliance with the research ethics standards. All mice received humane care and that study protocols comply with the institution's guidelines.

Mice were kept in polycarbonate metrolon plastic cages covered with a stainless-steel cover in the animal house at the College of Medicine at King Saud University in Riyadh, Saudi Arabia. The mice were exposed to $12 \mathrm{~h}$ of darkness and $12 \mathrm{~h}$ of light daily, and were kept under observation for 3 weeks. No evidence of sickness was observed. All mice were 12-14 weeks old at the start of the experiment.

This is a pilot study involving twenty mice simply divided into two groups that each consisted of ten mice. The unit of analysis for each dataset was group of animals. One group received SC injections of abatacept $(0.25 \mathrm{mg} / 0.03 \mathrm{ml} \mathrm{NS})$ at $0,2,4$ and 8 weeks. The second group received a SC injection of normal saline $(0.03 \mathrm{ml})$ weekly. We used weekly NS injection for this common control group because this study is considered as a part of multi-arm animal trials.

Since the appropriate dosage for SC injections of abatacept has not been reported in animals, we extrapolated this based upon recommended doses used in human studies. Ruperto et al.[17] injected children $(10-25 \mathrm{~kg}$ body weight) diagnosed with juvenile idiophathic arthritis with $50 \mathrm{mg}$ of abatacept. Thus abatacept sc $50 \mathrm{mg}$ for child weighing $10 \mathrm{~kg}$, corresponded to 0.125 mg weekly or $0.25 \mathrm{mg}$ every other week for the average mouse weighing $25 \mathrm{~g}$.

During the 10th week, mice were sacrificed by applying pressure to the neck and dislocating the cervical spine. Subsequently liver histopathological studies were performed for each mouse in both groups. The liver tissues were bisected and fixed in $10 \%$ buffered formalin for $24 \mathrm{~h}$. The tissues were then processed using hematoxylin and eosin $(\mathrm{H} / \mathrm{E})$ stain. The slides were examined using a light microscope. Evaluation of liver tissue slides were performed blindly by a histopathologist.

\section{Statistical Analysis}

Statistical differences between the abatacept-treated and saline-treated groups were calculated using Fisher's exact test. A $p$-value $<0.05$ was considered significant.

\section{Results}

Of the abatacept-treated mice, $3 / 10$ died during the last 3 weeks of the experiment. There was no clinical evidence of sickness prior to death. No deaths were reported in the control group.

Histopathological results are shown for the normal saline control group (Table 1) and the abatacept-treated group (Table 2). Liver changes were negative if all the histological features were normal (Fig. 1). Otherwise they remained positive. Positive liver tissues were observed in 6/7 mice treated with SC injections of abatacept (Table 2 and Fig. 2). In contrast, positive, mild liver changes were observed in 3/10 mice in the control group ( $p=$ 0.036). In two of these animals, the liver displayed lobules with mild inflammation and infiltration by lymphocytes. The liver of the third mouse (\#S7 mouse) presented with a parasite and granuloma (Fig. 3).

Table 1 Histopathological features of the control group

\begin{tabular}{lll}
\hline Mouse No. & Portal Tract & Liver Lobule \\
\hline S1 & Normal & Normal \\
S2 & Normal & Normal \\
S3 & Normal & Lymphocytes + \\
S4 & Normal & Lymphocytes + \\
S5 & Normal & Normal \\
S6 & Normal & Normal \\
S7 & lymphocytes++, histiocytes+ & Granuloma and parasite \\
S8 & Normal & Normal \\
S9 & Normal & Normal \\
S10 & Normal & Normal \\
\hline
\end{tabular}

Mild (+), Moderate (++), Marked (+++) 
Table 2 Histopathological features of the abatacept-treated group

\begin{tabular}{lll}
\hline Mouse No. & Portal Tract & Liver Lobule \\
\hline B1 & Granuloma, Eosinophils ++ lymphocytes++, histiocytes+ & Small Granuloma and eosinophils+ Apoptosis \\
B2 & Eosinophils+++, lymphocytes ++ , histiocytes+ & Small Granuloma and eosinophils++ Apoptosis + Focal EMH+ \\
B3 & neutrophils,+++ lymphocytes,++ histiocytes+ & Small Granuloma and eosinophils++ Apoptosis + \\
B4 & Eosinophils+, lymphoctes + , histiocytes + & Granuloma and eosinophils++ \\
B5 & Eosinophils+, lymphoctes + , histiocytes+ & Granuloma+++ and eosinophils++ \\
B6 & Normal & Normal \\
B7 & lymphocytes+ plasma cells, histiocytes+ & Focal EMH \\
\hline
\end{tabular}

EMH (extramedullary hematopoiesis)

Mild (+), Moderate (++), Marked (+++)

\section{Discussion}

Abatacept has recently been approved as a second-line treatment for RA and JIA. However, in systematic lupus erythematosus randomized clinical trials, this drug has failed to achieve its primary outcome [1-9, 11, 13, 18].

Abatacept demonstrated an acceptable safety profile which was also observed in different studies [13, 14]. In contrast, the present study, mortality was observed in $30 \%$ of the abatacept-treated mice despite using the recommended dose for JIA (as per body weight category above). Meanwhile, in the control group no mortality was reported. The husbandry was the same for both groups, and there were no clinical signs of sickness prior to death. The deaths were probably the result of cardiovascular events.

Rieke Alten et al. [15] investigated the safety of long-term SC abatacept injections using integrated analysis of clinical trial data for more than 4 years of treatment. Death occurred at an incidence rate of 0.59 (95\% confidence interval (CI): 0.40-0.88). Of the seven deaths

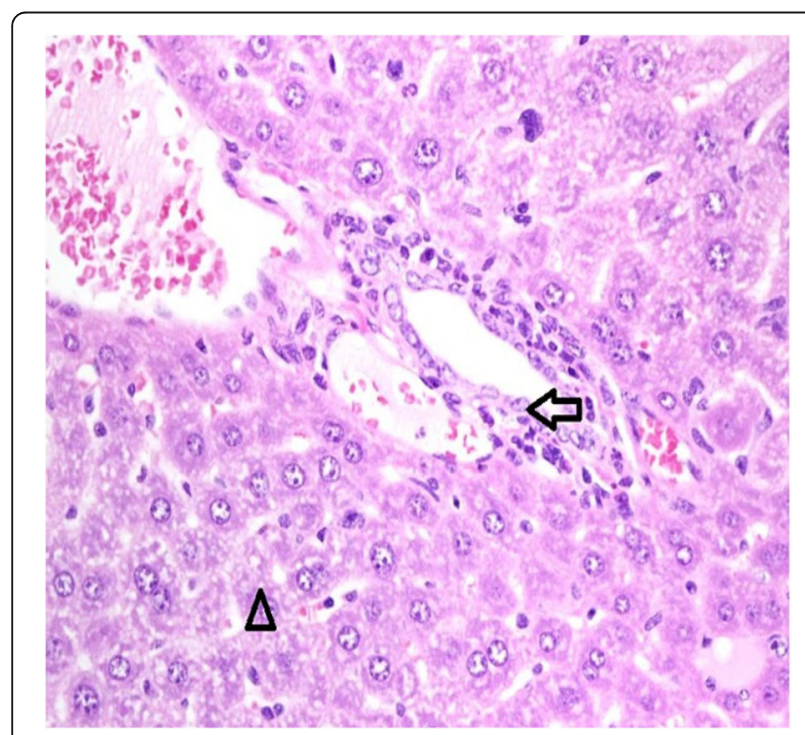

Fig. 1 Histology of a normal portal duct (arrow) and liver lobule (arrowhead) in control liver. H/E staining, 400× magnification classified as "certainly", "probably", or "possibly" related to the treatment, four were due to infections, one to a peritoneal neoplasm, one to a combination of a wound infection and malignant lung neoplasm, and one to multi-organ failure. An additional 18 deaths were considered unlikely to be related to the treatment. These deaths were most frequently the result of cardiovascular events.

Studies have documented the safety of abatacept in treating RA, including in patients with evidence of viral hepatitis [19-21].On the other hand cases of acute hepatitis $B$ viral infection reactivation have been reported in patients receiving this drug. Therefore, patients should be screened for hepatitis $B$ and $C$ before the start of therapy $[22,23]$.

For the sake of honesty we reported all the abnormal histopathological finding even in the control. We found

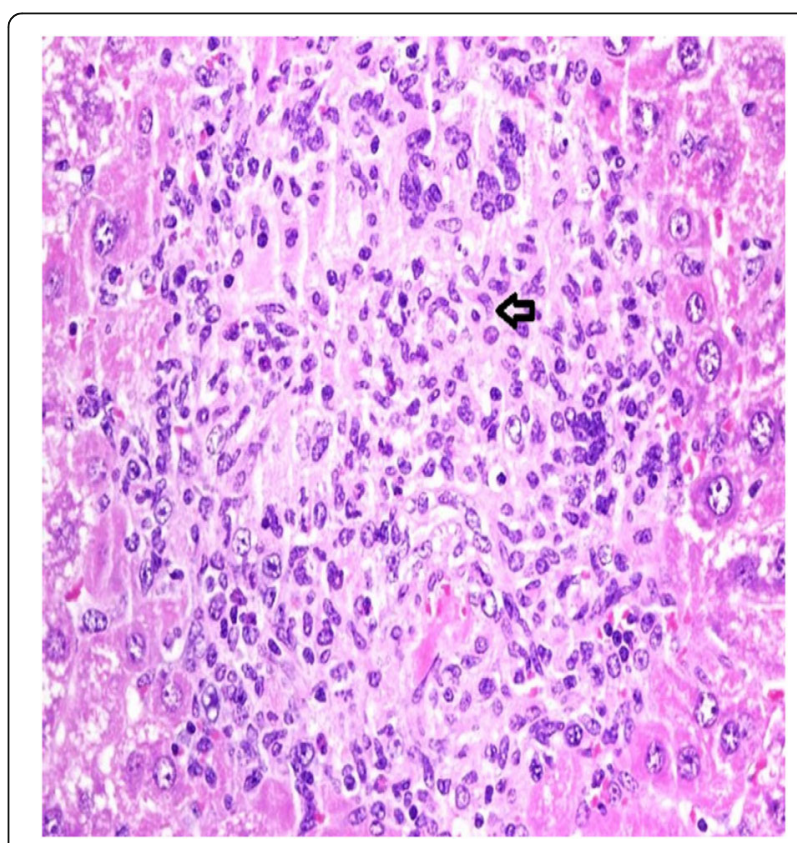

Fig. 2 Histology of an abatacept-treated liver reveals well-defined collection of epithelioid histiocytes (arrow) without necrosis. H/E staining, 400× magnification 


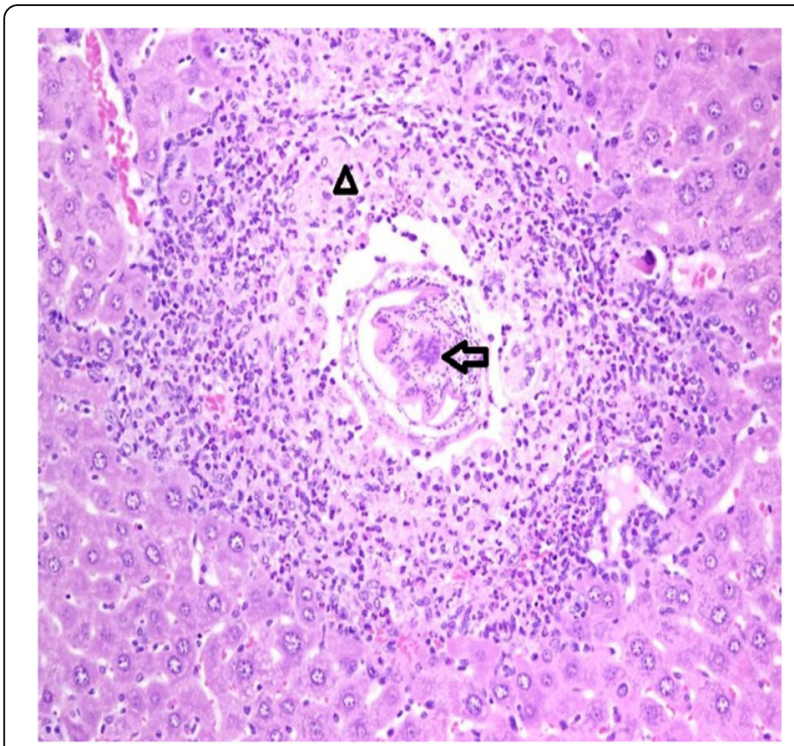

Fig. 3 Histology of mouse \#S7 control liver reveals epithelioid histiocytes (arrow head) surrounding a parasitic organism (arrow). H/ E staining, 200× magnification

only single hepatic granuloma surrounding a parasite of mouse $\mathrm{S} 7$, the background liver parenchyma was unremarkable without significant inflammation. This granuloma include a parasite helminth rather than unicellular protozoa, so it is not a leishmania, and in the absence of eggs it is unlikely to be schistosoma granuloma but probably it is a visceral larva migrans (Toxocariasis (T) ). BALB/c mice seem exceptionally susceptible to $T$. canis as larva counts are much higher compared to other strain. They usually did not show any clinical symptom [24].

Little information is available regarding the changes that occur in the liver following abatacept-treatment [16, 18-21]. Iwanaga $\mathrm{N}$ et al. [16] reported the occurrence of severe liver injury in abatacept-treated RA patient without reactivation of hepatitis B virus.

In the present study abatacept treated mice displayed significant histopathological changes in the liver $(p=$ 0.036 ) with respect to lobular cellular infiltration of eosinophils, lymphocytes, histiocytes with apoptosis and small granuloma formation.

Hepatic injury occurs as a result of different processes, including direct injury or autoimmunity. Since lobular inflammation and infiltration of eosinophils, histiocytes and lymphocytes with granuloma were observed in the absence of the characteristic histological features of autoimmune hepatitis including interface hepatitis, lymphocytic/ lymphoplasmacytic infiltrate without eosinophils presence [25-27], rarely granuloma are seen [28]. So most likely diagnosis is Abatacept induced granulomatous hepatitis but probably an overlapping syndrome could not be excluded [29-32].
We cannot rule out the possibility of autoimmune hepatitis unless the abatacept treated mice do not meet the simplified diagnostic criteria (2008). According to the simplified diagnostic criteria (2008) of the international autoimmune hepatitis group, selective elevation of $\operatorname{IgG}$ with autoantibodies is a hallmark of autoimmune hepatitis. These autoantibodies include ANA, anti-soluble liver antigen/liver-pancreas smooth-muscle antibodies (SMA), antibodies to liver-kidney microsomes (LKM) anti-soluble liver antigen/ liver-pancreas (SLA-LP) autoantibodies [33].

Granulomas are aggregates of modified macrophages (epithelioid cells) and other inflammatory cells that accumulate after chronic exposure to antigens so presence of granuloma in the absence of fibrosis probably more in favor subacute rather than chronic hepatitis [34].

Sarcoidosis-like reactions have been reported after treatment with TNF alpha blockade drugs [31, 32, 35], However, so far, no evidence in the literature to indicate that abatacept causes granulomatous hepatitis in humans, but probably because majority of patients with drug induced hepatic granuloma are asymptomatic and $60 \%$ of them are reported to have elevated transaminases but did not meet the criteria for liver biopsy. These will indicate the contrast between the limited liver injury in humans discovered by high transaminases and the findings of the current study [36-38]. Previous literature does not reflect the magnitude of drug-induced granulomatous hepatic disease and that many cases reported as "granulomatous hepatitis" consistent with "sarcoidosis" as well as many "undiagnosed" cases have a drug etiology. There have recently been reports of hepatic granulomas induced by drugs that had not previously been considered to be causal of this condition, and we therefore believe that many more drugs may potentially play a role in the development of hepatic granuloma [34, 39, 40].

Necrotizing granulomas in infectious disease processes often do not respect the architecture of the liver and may destroy adjacent structures. Necrotizing epithelioid granulomas quite frequently have an infectious etiology, and associated with Supportive inflammation .On the other hand necrotizing granuloma rarely induced by drugs. So it is unlikely that hepatic granuloma in Abatacept treated group is due to infection in immunocompromised mice [41].

\section{Conclusion}

To our knowledge this is the first control blinded study of BALB/c mice that has demonstrated granulomatous allergic hepatitis with sarcoidosis-like reaction following SC injections of abatacept.

Further experimental and clinical studies with transaminases, ANA, antimitochondrial antibodies (AMA) and serum-specific markers of autoimmune hepatitis are 
needed to determine the mechanisms underpinning abatacept-induced hepatitis.

Special histological stains, including the Ziehl-Neelsen (Zn) stain and fungal Grocott-Gomori's / Periodic acid-Schiff (GMS/-PAS) stains, are needed to better assess the granulomatous inflammatory reaction and rule out tuberculosis and fungal infections

\begin{abstract}
Abbreviations
AE: Adverse events; ANA: Anti-nuclear antibodies; CD: Cluster of Differentiation; Cl: Confidence interval; CTLA4: Cytotoxic T Lymphocyte Antigen-4; DMARD: Disease-Modifying Anti Rheumatic Drugs; GMS/PAS: Grocott-Gomori's / Periodic acid-Schiff; H/E: Hematoxylin and eosin; IgG: Immunoglobulin; JIA: Juvenile idiophathic arthritis; LKM: Liver-kidney microsomes; NS: Normal saline; RA: Rheumatoid arthritis; SAE: Serious Adverse events; SC: Subcutaneous; SLA-LP: Soluble liver antigen/ liverpancreas autoantibodies; SMA: Smooth-muscle antibodies; TNFi: Tumor Necrosis Factor alpha Inhibitor; Zn: Ziehl-Neelsen
\end{abstract}

\section{Acknowledgments}

The authors are thankful to College of Medicine Research Centre, Deanship of Scientific Research, King Saud University, Riyadh, Saudi Arabia for supporting the work. The author is also grateful to the histopathologist Dr. A. Al Humidi for the reporting of the histopathological studies.

\section{Funding}

This work was funded by the Deanship of Scientific Research at King Saud University, Riyadh, through research group no RGP-126. There was no role of the funding body in the design of the study, collection, analysis, and interpretation of data and in writing the manuscript. Author extends his appreciation to the Deanship of Scientific Research at King Saud University for funding this work through Research Group no RG RGP-VPP-126.

\section{Availability of data and materials}

All data and materials are available by e-mail on request.

\section{Author's contribution}

SMA designed the study, performed the analysis and interpretation of the data and wrote the manuscript. The author read and approved the final manuscript.

\section{Ethics approval and consent to participate}

The study protocol was approved by Research Ethics Committee at the College of Medicine, King Saud University, Riyadh. Consent to participate is not applicable.

\section{Consent for publication}

Not applicable.

\section{Competing interests}

The author declares that there are no competing interests.

\section{Publisher's Note}

Springer Nature remains neutral with regard to jurisdictional claims in published maps and institutional affiliations.

Received: 16 June 2018 Accepted: 22 April 2019

Published online: 07 May 2019

\section{References}

1. Balandraud N, Texier G, Massy E, Muis-Pistor O, Martin M, Auger I, et al. Long term treatment with abatacept or tocilizumab does not increase Epstein-Barr virus load in patients with rheumatoid arthritis - A three years' retrospective study. PLoS One. 2017;12:e0171623.

2. Chaabo K, Kirkham B. Rheumatoid Arthritis-Anti-TNF. Int Immunopharmacol. 2015;27(2):180-4.

3. Bonafede MM, Curtis JR, McMorrow D, Mahajan P, Chen Cl. Treatment effectiveness and treatment patterns among rheumatoid arthritis patients after switching from a tumor necrosis factor inhibitor to another medication. Clinicoecon Outcomes Res. 2016:8:707-15.

4. Singh JA, Saag KG, Bridges SL Jr, Akl EA, Bannuru RR, Sullivan MC, et al. 2015 American College of Rheumatology Guideline for the treatment of rheumatoid arthritis. Arthritis Rheum. 2016;68(1):1-26.

5. Bonafede M, Fox KM, Watson C, Princic N, Gandra SR. Treatment patterns in the first year after initiating tumor necrosis factor blockers in real-world settings. Adv Ther. 2012;29(8):664-74.

6. Soliman MM, Hyrich KL, Lunt M, Watson KD, Symmons DP, Ashcroft DM. British Society for Rheumatology Biologics Register. Rituximab or a second anti-tumor necrosis factor therapy for rheumatoid arthritis patients who have failed their first anti-tumor necrosis factor therapy? Comparative analysis from the British Society for Rheumatology Biologics Register. Arthritis Care Res. 2012;64(8):1108-15.

7. Harnett J, Wiederkehr D, Gerber R, Gruben D, Koenig A, Bourret J. Realworld evaluation of TNF-inhibitor utilization in rheumatoid arthritis. J Med Econ. 2016;19(2):91-102.

8. Chatzidionysiou K, van Vollenhoven R. Rituximab versus anti-TNF in patients who previously failed one TNF inhibitor in an observational cohort. Scand J Rheumatol. 2013;42(3):190-5.

9. Schiotis RE, Buzoianu AD, Mureșanu DF, Suciu S. New pharmacological strategies in rheumatic diseases. J Med Life. 2016;9(3):227-34.

10. Linsley PS, Wallace PM, Johnson J, Gibson MG, Greene JL, Ledbetter JA, et al. Immunosuppression in vivo by a soluble form of the CTLA-4 T cell activation molecule. Science. 1992;257(5071):792-5.

11. Rodrigues CE, Vieira FJ, Callado MR, Gomes KW, de Andrade JE, Vieira WP. Use of the abatacept in a patient with psoriatic arthritis. Rev Bras Reumatol. 2010;50(3):340-5.

12. Herrero-Beaumont G, Martínez Calatrava MJ, Castañeda S. Abatacept mechanism of action: Concordance with its clinical profile. Reumatol Clin. 2012;8(2):78-83.

13. Westhovens $R$, Verschueren $P$. The efficacy and safety of abatacept in rheumatoid arthritis. Ther Adv Musculoskelet Dis. 2010;2(2):89-94.

14. Sibilia J, Westhovens R. Safety of T-cell co-stimulation modulation with abatacept in patients with rheumatoid arthritis. Clin Exp Rheumatol. 2007; 25(Suppl 46):S46-56.

15. Alten R, Kaine J, Keystone E, Nash P, Delaet I, Genovese MC. Long-term safety of subcutaneous abatacept in rheumatoid arthritis: integrated analysis of clinical trial data representing more than four years of treatment. Arthritis Rheum. 2014:66(8):1987-97.

16. Iwanaga N, Origuchi T, Terada K, Ueki Y, Kamo Y, Kinoshita N, et al. Rheumatoid arthritis complicated with severe liver injury during treatment with abatacept. Mod Rheumatol. 2014;24(5):874-6.

17. Ruperto N, Lovell DJ, Tzaribachev N, Vega-Cornejo G, Louw I, Berman A, et al. Subcutaneous abatacept in patients with polyarticular juvenile idiopathic arthritis and inadequate response to biologic or non-biologic diseasemodifying antirheumatic drugs: pharmacokinetics, efficacy and safety. Ann Rheum Dis. 2016;75(Suppl 2):138.

18. Pimentel-Quiroz VR, Ugarte-Gil MF, Alarcón GS. Abatacept for the treatment of systemic lupus erythematosus. Expert Opin Investig Drugs. 2016;25(4): 493-9.

19. Padovan M, Filippini M, Tincani A, Lanciano E, Bruschi E, Epis O, et al. Safety of abatacept in rheumatoid arthritis with serologic evidence of past or present hepatitis B virus infection. Arthritis Care Res. 2016;68(6):738-43.

20. Kim PS, Ho GY, Prete PE, Furst DE. Safety and efficacy of abatacept in eight rheumatoid arthritis patients with chronic hepatitis B. Arthritis Care Res. 2012;64(8):1265-8.

21. Mahajan TD, Hooker R, Maher L, Brown G, Reimold A. Abatacept therapy for rheumatoid arthritis in the setting of hepatitis C infection. J Clin Rheumatol. 2010;16(7):332-4.

22. Nard FD, Todoerti M, Grosso V, Monti S, Breda S, Rossi S, et al. Risk of hepatitis $B$ virus reactivation in rheumatoid arthritis patients undergoing biologic treatment: Extending perspective from old to newer drugs. World J Hepatol. 2015;7(3):344-61.

23. Talotta R, Atzeni F, Sarzi PP. Reactivation of occult hepatitis B virus infection under treatment with abatacept: a case report. BMC Pharmacol Toxicol. 2016;17:17.

24. Strube C, Heuer L, Janecek E. Toxocara spp. infections in paratenic hosts. Vet Parasitol. 2013;193(4):375-89.

25. Sartin JS, Walker RC. Granulomatous hepatitis: a retrospective review of 88 cases at the Mayo Clinic. Mayo Clin Proc. 1991;66(9):914-8. 
26. Kleiner DE, Chalasani NP, Lee WM, Fontana RJ, Bonkovsky HL, Watkins PB, et al. Drug-Induced Liver Injury Network (DILIN). Hepatic histological findings in suspected drug-induced liver injury: systematic evaluation and clinical associations. Hepatology. 2014;59(2):661-70.

27. Suzuki A, Brunt EM, Kleiner DE, Miquel R, Smyrk TC, Andrade RJ, et al. The use of liver biopsy evaluation in discrimination of idiopathic autoimmune hepatitis versus drug-induced liver injury. Hepatology. 2011;54(3):931-9.

28. Geller SA. Autoimmune Hepatitis: Histopathology. Clin Liver Dis. 2014;3(2): 19-23.

29. Fisher K, Vuppalanchi R, Saxena R. Drug-Induced Liver Injury. Arch Pathol Lab Med. 2015;139(7):876-87.

30. Metyas SK, Tadros RM, Arkfeld DG. Adalimumab-induced noncaseating granuloma in the bone marrow of a patient being treated for rheumatoid arthritis. Rheumatol Int. 2009;29(4):437-9.

31. Kanellopoulou T, Filiotou A, Kranidioti H, Dourakis SP. Sarcoid-like granulomatosis in patients treated with anti-TNFa factors. A case report and review of the literature. Clin Rheumatol. 2011;30(4):581-3.

32. Cathcart S, Sami N, Elewski B. Sarcoidosis as an adverse effect of tumor necrosis factor inhibitors. J Drugs Dermatol. 2012;11(5):609-12.

33. Hennes EM, Zeniya M, Czaja AJ, Parés A, Dalekos GN, Krawitt EL, et al. International autoimmune hepatitis group. Simplified criteria for the diagnosis of autoimmune hepatitis. Hepatology. 2008;48(1):169-76.

34. Coash M, Forouhar F, Wu CH, Wu GY. Granulomatous liver diseases: a review. J Formos Med Assoc 2012: 111(1):3-13.

35. Gifre L, Ruiz-Esquide V, Xaubet A, Gómez-Puerta JA, Hernández MV, Sanmartí R. Lung sarcoidosis induced by TNF antagonists in rheumatoid arthritis: a case presentation and a literature review. Arch Bronconeumol. 2011;47(4):208-12

36. Iqbal U, Siddiqui HU, Anwar H, Chaudhary A, Quadri AA. AllopurinolInduced Granulomatous Hepatitis: A Case Report and Review of Literature. J Investig Med High Impact Case Rep. 2017;5(3):2324709617728302.

37. McMaster KR 3rd, Hennigar GR. Drug-induced granulomatous hepatitis. Lab Investig. 1981;44(1):61-73.

38. Yu YC, Mao YM, Chen CW, Chen JJ, Chen J, Cong WM, et al. Drug-induced Liver Injury (DILI) Study Group; Chinese Society of Hepatology (CSH); Chinese Medical Association (CMA). CSH guidelines for the diagnosis and treatment of drug-induced liver injury. Hepatol Int. 2017;11(3):221-41.

39. Culver EL, Watkins J, Westbrook RH. Granulomas of the liver. Clin Liver Dis. 2016;7(4):92-6.

40. Abe M, Kumagi T, Nakanishi S, Yamagami T, Michitaka K, Abe K, et al. Druginduced hepatitis with hepatic granuloma due to saridon. J Gastroenterol. 2002;37(12):1068-72.

41. Lamps LW. Hepatic Granulomas: A Review with Emphasis on Infectious Causes. Arch Pathol Lab Med. 2015:139(7):867-75.

Ready to submit your research? Choose BMC and benefit from:

- fast, convenient online submission

- thorough peer review by experienced researchers in your field

- rapid publication on acceptance

- support for research data, including large and complex data types

- gold Open Access which fosters wider collaboration and increased citations

- maximum visibility for your research: over $100 \mathrm{M}$ website views per year

At $\mathrm{BMC}$, research is always in progress.

Learn more biomedcentral.com/submissions 